\title{
THE ROLE OF FIRST-BEST GOVERNANCE INSTITUTIONS ON GROWTH IN LEAST DEVELOPED COUNTRIES
}

\author{
EN AZ GELİ̧Mİ̧ ÜLKELERDE BİRINCİ EN İYİ YÖNETİ̧̧IM \\ KURUMLARININ BÜYÜME ÜZERİNE ETKİSI
}

\section{Adem GÖK ${ }^{*}$}

\begin{abstract}
The study addresses the issue of the low level of GDP per capita growth in Least Developed Countries (LDCs), with special emphasis on the role of first-best governance institutions as a main determinant of growth. LDCs can be characterized by a clear deficit in first-best governance institutions compared to high-income OECD countries supporting the argument that economies that are different for a variety of reasons will differ both in their institutions and in their income per capita. The contribution of the study is to fill the gap in the new political economy of growth by establishing the mechanism of how first-best governance institutions affect growth through the political, economical, administrative and democratic channels. Although the adoption of first-best governance institutions of advanced countries to LDCs is not a panacea to sustainable economic growth, improvement of first-best governance institutions in LDCs significantly induce growth, since investments in governance institutions are subject to diminishing returns, so that the benefits are most pronounced for smaller and developing economies.
\end{abstract}

Keywords: Governance, LDCs, Growth, PCA, System GMM

JEL Classification: C33, E02

\section{Özet}

Çalışma, özellikle birinci en iyi yönetişim kurumlarının ekonomik büyümenin ana belirleyicisi olması vurgusuyla, En Az Gelişmiş Ülkeler (EAGÜ)' de düşük seviyeli ekonomik büyümeyi incelemektedir. Yüksek gelirli OECD ülkeleriyle karşılaştırıldığında EAGÜ birinci en iyi yönetişim kurumlarında göze çarpan olumsuz yöndeki açık, bir çok nedenden ötürü farklılaşan ekonomilerin yönetişim kurumları ve kişi başına düşen gelir seviyeleri açısından farklılık göstermeleri tartışmasını desteklemektedir. Çalışmanın katkısı, birinci en iyi yönetişim kurumlarının nasıl bir mekanizmayla ekonomik büyümeyi politik, iktisadi, idari ve demokratik kanallarla etkilediğini ortaya koyarak yeni politik büyüme iktisadındaki bu boşluğu doldurmaktır. Her ne kadar EAGÜ’in ülkelerdeki birinci en iyi yönetişim

* Corresponding Author, Research Assistant Dr., Kurklareli University Department of Economics, Kayalı Campus, Kırklareli, adem.gok@klu.edu.tr, Orcid Id: 0000-0002-3786-2507 
kurumlarını kendilerine adapte etmeleri sürdürülebilir ekonomik büyümeye çözüm olmasa da, EAGÜ’indeki birinci en iyi yönetişim kurumlarındaki iyileşmeler önemli ölçüde ekonomik büyümeye yol açmaktadır. Zira, yönetişim kurumlarına yapılan yatırımlar azalan verimler yasasına uyduğu için, bu yatırımların faydaları daha küçük ve gelişmekte olan ülkeler için en çoktur.

Anahtar Kelimeler: Yönetişim, EAGÜ, Büyüme, TBA, Sistem GMM

JEL Sınıflandırması: C33, E02

\section{I.Introduction}

The most fundamental question in the field of economic growth and development is concentrated on the reasons behind the large differences in the welfare of states or more specifically, the fundamental causes of the large differences in income per capita across countries ${ }^{1}$.

Capital accumulation, technological improvement, education, economies of scale, and other Barro regressors are not the causes of growth, but they are growth ${ }^{2}$. These indicators can only be the approximate causes of growth, the main reason for income per capita differences ${ }^{3}$, hence the growth is the difference in governance quality across countries. Hence the fundamental reason and the explanation of the difference between the welfare of states; thus the touchstone of the differing paths of economic growth leading to more or less developed status of the states, is the quality of institutions. Countries that have well-established governance institutions will invest more in both physical and human capital by using these factors more efficiently in order to achieve greater level of income per capita ${ }^{4}$.

The main issue of the study is to determine the reasons for the low level of growth in the LDCs, with special emphasis given to the role of governance institutions as a main determinant of growth.

A broad consensus among growth economists, development experts and aid donors is that 'good governance' is a pre-requisite for sustained increase in living standards of the society. Although the literature has made important advances in uncovering the political, institutional and social determinants of growth, the new political economy of growth still lacks a proper grasp of the channels through which institutions affect growth and the political sources of good institutions ${ }^{5}$.

1 Acemoğlu, D. et al. (2001). The Colonial Origins of Comparative Development: An Empirical Investigation, American Economic Review, 91(5): 1369-1401.

2 North, D. C., Thomas, R. P., (1973). The Rise of the Western World: A New Economic History, Cambridge University Press.

3 Acemoğlu, D. et al. (2005). Institutions as a Fundamental Cause of Long-Run Growth, Handbook of Economic Growth, 1: 385-472.

4 Acemoğlu et al., 2001.

5 Dellepiane-Avellaneda, S. (2010). Good Governance, Institutions and Economic Development: Beyond the Conventional Wisdom, British Journal of Political Science, 40(1): 195-224. 
Governance structure of a country should be defined and measured by its politic, economic, administrative and democratic stand against internal and external events. This definition of governance is parallel to the above argument of North ${ }^{6}$ that administration and democratization in a country forms the social interaction within the society.

Based on Aysan et al. ${ }^{7}$, four dimensions of governance at the national level or politic, economic, administrative and democratic stand of a country against internal and external events in other words, is measured by political stability, economic stability, administrative quality and public voice by principal component analysis of several indices taken from ICRG ${ }^{8}$ and $\mathrm{FRH}^{9}$.

The notion of getting institutions right since the declaration of Washington Consensus requires the adoption of governance institutions in developed countries to LDCs for granting official development assistance and official aid by UN or donor countries. LDCs, which are generally extractive states ${ }^{10}$, did not find a chance to establish their own governance institutions since they are ruled by the regimes of colonizers for many years. When they thought they won their independence, they have been ruled by totalitarian regimes left behind ${ }^{11}$ and supported by ex-colonizers of distant past and advanced countries of today. Rulers left their subordinate authoritarian regimes to interfere in their ex-colonies by referring as non-democratic, corrupted regimes. LDCs generally never had a chance to establish their own governance institutions compatible with their historical, economical and social background. However, advanced countries of today have learned by their best mistakes in the colonization of their subdued extractive states. They established their governance institutions according to their own internal dynamics of historical and cultural background, customs, economic practices, belief and legal system based on their experiences both on their mainland and colonies. They accumulated wealth through colonization process to sustain their governance structures on a worldwide basis to be taken as a role model. That's why colonizers of past and advanced countries of today have the highest governance quality in the world. They set the rules of the game and the game is still played according to their rules.

The contribution of the study is to fill the gap in the new political economy of growth by establishing the mechanism of how governance institutions affect growth through the political, economical, administrative and democratic channels by concentrating on the growth incapability of LDCs especially resulting from bad governance as a main structural impediment to growth.

LDCs can be characterized by a clear deficit in governance institutions compared to high-income OECD countries supporting the argument that economies that are different for a variety of reasons will differ both in their institutions and in their income per capita.

6 North, D. C. (1991). Institutions, The Journal of Economic Perspectives, 5(1): 97-112.

7 Aysan, A. F. et al. (2007). Governance Institutions and Private Investment: An Application to the Middle East and North Africa, The Developing Economies, 45(3): 339-377.

8 ICRG (2011). International Country Risk Guide, PRS Group, New York.

9 FRH (2012). Freedom in the World Database, Freedom House, New York.

10 Acemoğlu et al., 2001.

11 Etzioni, A. (2008), Security First: For a Muscular, Moral Foreign Policy, Yale University Press. 
Although the adoption of first-best governance institutions of advanced countries to LDCs is not a panacea to sustain economic growth ${ }^{12}$, improvement in first-best governance institutions significantly induce growth in LDCs. The main rationale is that investment in governance infrastructure are subject to diminishing returns, so that the benefits are most pronounced for smaller and developing economies including $\mathrm{LDCs}^{13}$.

Next section presents literature review and third section presents theoretical background. A new theoretical perspective for FDI theory is developed in third section. Fourth section explains how governance affects growth. Fifth section presents data and variables used in the study. Governance and income per capita performance of LDCs compared with high income OECD countries are presented in sixth section. Seventh section presents empirical analysis and last section provides conclusion.

\section{Literature Review}

There is no empirical study in the literature specifically analyzing the role of governance on growth in LDCs. But, there are numerous studies analyzing the role of governance on growth in full sample of countries including developed and developing or just developing countries. The following studies, either criticizing or building on Knack and Keefer ${ }^{14}$, Rodrik ${ }^{15}$, Acemoğlu et al. ${ }^{16}$, are presented.

Based on North and Thomas ${ }^{17}$ and Acemoğlu et al. ${ }^{18}$, Angeles ${ }^{19}$ argued that factors such as private investment, human capital and international trade are proximate determinants of economic growth; they are the outcome of deeper determinants such as institutional quality and their inclusion would pick up some of the growth effects that should ultimately be ascribed to institutions. Hence, he analyzed the role of governance on growth of income per capita by excluding proximate causes of growth with panel fixed-effect to control differences in deep determinants of growth, such as climate, geography, culture and history across countries. He preferred panel data analysis over cross-country analysis based on the argument that only panel data analysis represents within-country variation in actual institutional changes taking place inside a country. He found no evidence of a positive significant effect of governance, which is proxied only by a democracy index of Polity IV, on growth. Although he criticizes the potential endogenenity problem stemming from cross-sectional analysis of Hall and Jones ${ }^{20}$, Acemoğlu

12 Rodrik, D. (2008). Second-Best Institutions, American Economic Review, 98(2): 100-104.

13 Globerman, S., Shapiro, D. (2002). Global Foreign Direct Investment Flows: The Role of Governance Infrastructure, World Development, 30(11): 1899-1919.

14 Knack, S., Keefer, P. (1995). Institutions and Economic Performance: Cross-Country Tests Using Alternative Institutional Measures, Economics \& Politics, 7(3): 207-227.

15 Rodrik, 2008.

16 Acemoğlu et al., 2001.

17 North and Thomas, 1973.

18 Acemoğlu et al., 2015.

19 Angeles, L. (2010). Institutions and Economic Development. New Tests and New Doubts, Sire, No: 2010-75.

20 Hall, R. E. Jones, C. I. (1999). Why do some Countries Produce so much more Output per Worker than others?, The 
et al. ${ }^{21}$, Easterly and Levine ${ }^{22}$, Rodrik et al. ${ }^{23}$, Feyrer and Sacerdote ${ }^{24}$, the endogeneity problem in his fixed effect panel setting is more severe due to the variation across time within countries.

Based on theoretical background of Dawson ${ }^{25}$, Hall and Ahmad $^{26}$ analyzed the role of governance on per capita income in 69 developing countries including developing East Asian sample for the period 1985-2008 with system GMM. They found that security of property rights proxied by investment profile have positive significant effect on per capita income, hence growth both in whole sample and East Asian sample. They also found that political rights has a significant positive impact on growth for the East Asian sample in pooled OLS supporting the argument of Ahrens ${ }^{27}$ that autocratic government causing growth in the region. But it turns out to be insignificant in the system GMM estimation, which controls endogeneity problem stemming from reverse causality. Law and order, and bureaucratic quality proxied by government stability have no significant effect on growth in both samples according to the results of system GMM estimation. The results do not change when they controlled Asian financial crisis in 1997 by dividing East Asian sample into two period as pre-crisis and after-crises. Hence they concluded that secure property rights and strong government are the key determinants of growth, although their system GMM estimation results only support secure property rights are the only key determinant of growth.

Based on the governance indices used by Knack and Keefer ${ }^{28}$, Chong and Chalderon ${ }^{29}$ found a statistically significant bidirectional relationship between governance and growth rate of income per capita by employing VAR analysis. For the whole sample of 55 countries for the period 1972-1995, they could not find any effect of governance variables on growth. For the sample of 35 developing countries for the same period, they found that governance quality is a significant predictor for subsequent economic growth for all the indices of governance except enforceability of contracts. They concluded that policies that efficient policy reform, which improves the delivery of bureaucracy, secures property rights, cracks down on corruption, reduces uncertainty, though important for economic growth, takes

Quarterly Journal of Economics, 114(1): 83-116.

21 Acemoğlu et al., 2001.

22 Easterly, W., Levine, R. (2003). Tropics, Germs, and Crops: How Endowments Influence Economic Development, Journal of Monetary Economics, 50(1): pp.3-39.

23 Rodrik, D. et al., (2004). Institutions Rule: The Primacy of Institutions over Geography and Integration in Economic Development, Journal of Economic Growth, 9:131-165.

24 Feyrer, J., Sacerdote, B. (2009). Colonialism and Modern Income: Islands as Natural Experiments, The Review of Economics and Statistics, 91(2): 245-262.

25 Dawson, J. W. (1998). Institutions, Investment, and Growth: New Cross-country and Panel Data Evidence, Economic Inquiry, 36(4): 603-619.

26 Hall, S. G., Ahmad, M. (2014). Revisiting the Institutions-Growth Nexus in Developing Countries: The New Evidence, New Zealand Economic Papers, 48(3): 301-312.

27 Ahrens, J. (2002). Governance and Economic Development: A Comparative Institutional Approach, Edward Elgar Publishing.

28 Knack and Keefer, 1995.

29 Chong, A., Calderon, C. (2000). Causality and Feedback between Institutional Measures and Economic Growth, Economics \& Politics, 12(1): 69-81. 
considerable time to bear fruit. Hence, they also concluded that the poorer the country and the longer the wait, the higher the influence of institutional reform on economic growth.

By using the settler mortality rates of Acemoğlu et $a .^{30}$ to instrument governance, Decker and Lim ${ }^{31}$ employed cross-sectional 2SLS analysis for 91 countries for 1995 and system GMM panel data analysis for 128 countries for the period 1984-2002, in order to determine the role of governance on per capita income. They found no evidence that democracies grow faster or slower than non-democracies in both cross-sectional and panel data analysis. They found that governance variables are positive significant determinants of GDP per capita, hence growth according to both cross-section and panel data estimations. They also found that oil-exporting countries do appear to perform better in cross-section analysis and the positive effect of institutions diminishes over time, although this effect is not consistently significant across all specifications according to panel data analysis.

Efendic et al..$^{32}$ employed meta-regression analysis (MRA) to identify if there is a representative empirical effect of institutional quality on economic performance and, if so, to measure the size of this effect. Their analysis includes 112 regression estimates from 40 empirical studies as whole sample consisting of two sub-samples as 52 estimates from 20 studies using output-growth as dependent variable and 60 estimates from 21 studies using output-level. For both the full sample and the subsample of studies concerned with levels of economic performance (output-level) reveals no evidence of publication bias while suggesting the possible presence of an authentic, positive and large empirical effect. In contrast, for the sub-sample of studies concerned with economic growth (output-growth) reveals evidence of substantial, positive publication bias but finds no evidence suggesting an authentic empirical effect. They determined three source of heterogeneity in the literature. First, studies using income per capita levels reveal a more robust representative effect than studies using the growth rate of income per capita as a dependent variable. Second, model specification is another major source of heterogeneity, which particularly affects the levels sample. Third, studies that account for endogeneity problem tend to report a substantially smaller effect of institutional quality on economic performance than do other studies, for both the growth and level samples.

\section{Theoretical Background}

The basic theoretical framework used for the analysis in the study is taken from Dawson ${ }^{33}$, which is an extension of MRW model ${ }^{34}$.

30 Acemoğlu et al., 2001.

31 Decker, J. H., Lim, J. J. (2008). What Fundamentally Drives Growth? Revisiting the Institutions and Economic Performance Debate, Journal of International Development, 20(5): 698-725.

32 Efendic, A. G. et al. (2011). Institutions and Economic Performance: A Meta-Regression Analysis, European Journal of Political Economy, 27(3): 586-599.

33 Dawson, 1998.

34 Mankiw, N. G. et al., (1992). A Contribution to the Empirics of Economic Growth, The Quarterly Journal of Economics, 107(2): 407-437. 
Dawson $^{35}$ assumes a Cobb-Douglas production function, which exhibits constant returns to scale but diminishing returns to each factor individually.

(1) $Y_{t}=K_{t}^{\alpha} H_{t}^{\beta}\left(A_{t} L_{t}\right)^{1-\alpha-\beta}$;

$$
\alpha, \beta>0, \alpha+\beta<1
$$

where $\mathrm{Y}$ is aggregate output, $\mathrm{K}$ is physical capital, $\mathrm{H}$ is human capital, $\mathrm{L}$ is labor and $\mathrm{A}$ is the level of technology. Labor and technology are assumed to grow exogenously at $\mathrm{n}$ and g, respectively. Physical and human capital depreciates at constant rate, $\delta$ and $s_{h}$, respectively.

The speed of convergence to steady-state level is;

$$
\varphi=(n+g+\delta)(1-\alpha-\beta)
$$

The following estimation equation is derived;

(2) $\ln y_{T}-\ln y_{0}=\pi_{0}+\pi_{1} \ln y_{0}+\pi_{2} \ln (n+g+\delta)+\pi_{3} \ln s_{k}+\pi_{4} \ln s_{h}$;

$$
\text { subject to } \pi_{3}+\pi_{4}=-\pi_{2}
$$

where $\mathrm{y}$ is output per worker, and the subscripts 0 and $\mathrm{T}$ refer to initial and terminal dates of the period, respectively.

Dawson ${ }^{36}$ offers two extensions of the $\mathrm{MRW}^{37}$ model to illustrate the potential effects of governance on growth. The first effect of governance on growth is an indirect effect that the governance affects growth through investment channel. The second effect of governance on growth is a direct effect that the governance affect total factor productivity.

Dawson's ${ }^{38}$ extension for the investment channel assumes the saving share, $s_{k}$, to be constant over time and a function of governance quality, F such that $s_{k}>0$. Although $s_{k}$ is assumed to be constant over time within an economy, different economies with different governance quality with different value of $\mathrm{F}$ will have a different value of $s_{k}$.

Based on Besley ${ }^{39}$ (1995), Dawson ${ }^{40}$ argues that secure property rights may protect the fruits of investment from expropriation, enforcement of contracts and favorable governance of credit markets may eliminate barriers to carry out investment, and finally good governance facilitating economic transactions between individuals and firms may enhance the gains from trade and therefore, increase the potential return to investment.

35 Dawson, 1998.

36 Dawson, 1998.

37 Mankiw et al., 1992.

38 Dawson, 1998.

39 Besley, T. (1995). Property Rights and Investment Incentives: Theory and Evidence from Ghana, Journal of Political Economy, 103(5): 903-937.

40 Dawson, 1998. 
Dawson's $^{41}$ extension for the effect of governance on total factor productivity assumes the technology, A, is a function of governance. Although technology evolves exogenously as in the traditional neoclassical model, the differences in governance have a fixed effect on the level of productivity across countries. He derived the following equation to replace equation (2) in order to measure the direct effect of governance on total factor productivity.

(3) $\ln y_{T}-\ln y_{0}=\pi_{0}+\pi_{1} \ln y_{0}+\pi_{2} \ln (n+g+\delta)+\pi_{3} \ln s_{k}+\pi_{4} \ln s_{h}+\pi_{5} \ln F$

Dawson ${ }^{42}$ argues that the measure of governance in the equation (3) has little or no explanatory power, if governance institutions operate predominantly through the investment channel. Including a measure of governance in a growth regression as in equation (3) can be expected to add explanatory power, if governance institutions operate primarily through a direct effect. If governance institutions work through both channels simultaneously, the inclusion of governance variable as in equation (3) should add explanatory power and reduce the estimated size and significance of investment channel.

The study is built on Dawson's model ${ }^{43}$ by assuming that governance work through both channels simultaneously.

Model (3) can be extended to include trade openness and official assistance and aid. They are no more a part of constant term $\left(\pi_{0}\right)$. Based on Model 3, Model 4 is developed.

$$
\begin{aligned}
(4) \ln y_{T}-\ln y_{0}=\pi_{0}+\pi_{1} \ln y_{0} & +\pi_{2} \ln (n+g+\delta)+\pi_{3} \ln s_{k}+\pi_{4} \ln s_{h}+\pi_{5} \ln F+ \\
& \pi_{6} \text { trop }+\pi_{7} \ln a a
\end{aligned}
$$

\section{The Mechanism for the Effect of Governance on Growth}

Governance structure of a country should be defined and measured by its politic, economic, administrative and democratic stand against internal and external events.

Political dimension of governance affects growth performance of countries through both channels. Politically unstable countries have higher amount of internal and external conflicts. Due to these conflicts, governments are unstable and the probability of civil disobedience is high. Hence the protection of private property is hard to sustain. The indirect effect of political stability on growth is through investment channel. Hence the political instability affects the investment profile of the countries in the following way. Lack of well-established protection of property rights, risk-averse domestic investors may hesitate to take economic initiatives or may exit the economy by investing abroad. The foreign investors may shift their subsidiaries to other advantageous countries that are

\footnotetext{
41 Dawson, 1998.

42 Dawson, 1998.

43 Dawson, 1998.
} 
politically more stable ${ }^{44}$. The direct effect of political stability on growth through total factor productivity is as follows. Political instability is likely to shorten policymakers' horizons leading to sub-optimal short term macroeconomic policies and thus, negatively affecting macroeconomic performance ${ }^{45}$. Political instability also affects growth through physical and human capital accumulation leading to decrease in total factor productivity.

Economic dimension of governance affects growth performance of countries through investment channel. Investors consider the costs and returns on their investment projects. If an economy is governed by inadequate and inconsistent economic policies and turns into unstable one, it constitutes the major cause of unpredictable high costs. Returns on investment projects, which seem profitable at the beginning, turn into losses mainly due to the exchange rate risks and inflation. Economic instability increases uncertainty and risks, which are detrimental to investment. Hence, either domestic or foreign investors prefer economically more stable countries or just invest in if they predicted that the time required to exploit full return on investment comes before the time of the economy becomes unstable.

Administrative dimension of governance affects growth mainly through investment channel. It includes bureaucratic quality of country, the country's stand against corruption and protection of investors against expropriation. Investors evaluate the performance of bureaucracy based on how responsive is the system to the need of investors, does it take too much time and effort even to initiate simple steps of investment plans, whether investor have to deal with red tape. Hence the inefficiencies in bureaucracy are a detrimental factor for investment, because it increases the time for implementation of investment plans; hence it increases the costs of investment due to time lags. Extensiveness of corruption for the initiation of investment decision has two effects on the competitive market structure. The first one is the case where public officials impose their corruption practices on investors. In this case the price mechanism is harmed to the increase in cost due to corruption practices. The second one is that investors suborn public officials in order to access better terms or privileges. The last constituent of administrative dimension of governance structure is the extent of protection of investor rights. Investors also consider the protection against expropriation, contract viability by the risk of unilateral contract modification or cancellation, and payment delays by the extent that profits can be transferred out of the country. Wellestablished administrations also affect growth through increasing total factor productivity by using resources more efficiently especially for the case of education, public services and legal system ${ }^{46}$.

Last dimension of governance is the stand of the country with respect to democracy. Democracy affects growth through both channels simultaneously. Democratic institutions provide checks and balances on elected officials, which in turn reduces arbitrary government intervention, lowers the risk of policy reversal and strengthen private property protection ${ }^{47}$. The type of products and services

44 Alesina A., Perotti, R. (1994). The Political Economy of Growth: A Critical Survey of the Recent Literature, The World Bank Economic Review, 8(3): 351-371.

45 Aisen, A., Veiga, F. J. (2013) How does Political Instability Affect Economic Growth?, European Journal of Political Economy, 29: 151-167.

46 St Aubyn, M. (2008). Modernising Public Administration and Economic Growth, Gpeari Working Paper, No: WP-001.

47 Asiedu, E. Lien, D. (2011). Democracy, Foreign Direct Investment and Natural Resources, Journal of International 
supplied to domestic markets are highly sensitive to the preferences of consumers if the consumer rights are well protected. Any reduction in the quality of goods and services offered to domestic consumers or any harm given to environment or public health is confronted with public reaction either by the legal system which provides those rights to consumers through lawsuits or by democratic actions through boycott, rallies, assembly against producers. Hence investors take this reality into account at the planning stage of their investment. Improvement in the protection of consumer rights either through legal system or democratic rights of the public do not constitute a detrimental factor for investment. On the contrary, they enlarge the preference set of consumers, which lead to increased amount of investment and consumption.

\section{Data and Variables}

The study covers 24 LDCs for Section 6 and 21 LDCs in Section 7 for the period 1991-2010 due to the data availability. (See Appendix 1 for the list of LDCs covered in the study).

All the variables are taken stationary according to the results of the panel unit root tests. (See Appendix 2 for the results of panel unit root tests).

\section{I.GDP per capita (Ingdppc)}

Natural logarithm of GDP per capita, PPP (constant 2011 international \$) from WDI ${ }^{48}$ is used as dependent variable.

\subsection{Lag of GDP per capita (I.Ingdppc)}

It is the predetermined value of one-year lag value of natural logarithm of GDP per capita, PPP (constant 2011 international \$) from WDI ${ }^{49}$ is used.

Due to high collinearity among the indices, Principal Component Analysis (PCA) is used to derive governance variables and human capital.

\subsection{Governance Variables}

The author is benefitted from Aysan et al. ${ }^{50}$ and ICRG variable definitions of PRS ${ }^{51}$ while establishing his own stand. The three governance indicators; political stability index, administrative

Economics, 84(1): 99-111.

48 WDI (2017), World Development Indicators, The World Bank, Washington D.C.

49 WDI, 2017.

50 Aysan et al., 2007.

51 ICRG, 2011. 
quality index and public voice index are based on governance indicators developed by Aysan et.al. ${ }^{52}$. But, the reason to include these indicators, the motivation behind using them and the sub-indices of the indicators differ from Aysan et.al. ${ }^{53}$. Economic stability is generally proxied by inflation rate in the literature as a macroeconomic indicator instead of a dimension of governance.

\subsection{I.Political Stability Index (psi)}

This index is constructed by PCA of five indices from ICRG (2011); government stability (gs), external conflict (ec), internal conflict (ic), ethnic tensions (et), and religious tensions (rt).

\subsubsection{Economic Stability Index (esi)}

This index is constructed by PCA of six indices from ICRG (2011); risk for budget balance (rfbb), risk for current account ( $\mathrm{rfca}$ ), risk for exchange rate stability (rfers), risk for foreign debt (rffd), risk for inflation (rfi), and risk for international liquidity (rfil).

\subsubsection{Administrative Quality Index (aqi)}

This index is constructed by PCA of four indices from ICRG (2011); bureaucracy quality (bq), corruption (cor), investment profile (ip), and law and order (lao).

\subsubsection{Public Voice Index (pvi)}

This index is constructed by PCA of four indices; democratic accountability (da) and military in politics (mip) from ICRG (2011), civil liberties (cl) and political rights (pr) from FRH (2011).

\subsubsection{Overall Governance Index (govi)}

This index is constructed by PCA of nineteen sub-indices used to create four dimensions of governance above.

Although these indices are subjective and outcome-based rather than representing the quality of actual institutions, deficiencies in these governance perceptions depend on experts' views and surveys, which do not constitute a severe problem in analyzing the effects of governance on growth. Because, the private investors, donor countries or WTO takes these kinds of governance data into consideration for investment or aid decisions for LDCs at the time of investment or aid. Thus like a self-fulfilling prophecy, the true governance perceptions are realized according to these possibly subjective deficient governance perceptions.

52 Aysan et al., 2007.

53 Aysan et al., 2007. 
The higher values of indices from $\mathrm{ICRG}^{54}$ represent better governance quality, while lower values of indices from $\mathrm{FRH}^{55}$ represent better governance quality. All indices are rescaled after two indices taken from $\mathrm{FRH}^{56}$ are converted in a way that higher values correspond to better governance quality.

All governance variables are endogenous due to reverse causality problem based on the argument that rich countries can afford better governance institutions ${ }^{57}$.

\subsection{Human Capital (humcap)}

This index is constructed by PCA of adult literacy rate (lr), gross primary enrollment rate (pser), gross secondary enrollment rate (sser), gross tertiary enrollment rate (tser), life expectancy at birth (le), and mortality rate (mr) taken from WDI ${ }^{58}$. It is treated as an endogenous variable since growth in per capita income lead to improvement both in the educational opportunities and heath conditions in the society.

\subsection{Physical Capital (gfcf)}

Gross fixed capital formation (\% GDP) is taken from WDI ${ }^{59}$ to proxy this variable. It is taken as endogenous due to the fact that growth leads to the increase in investment.

\subsection{Trade Openness (Introp)}

Trade $\%$ of GDP is taken from $\mathrm{WDI}^{60}$ to proxy this variable. It is taken as an endogenous variable due to the fact that growth leads to the deeper integration into the global trade by providing economies of scale in production leading to higher exports and higher aggregate consumption leading to higher imports.

\subsection{Official Assistance and Aid (Inaa)}

Net official development assistance and official aid received is taken from WDI ${ }^{61}$. It is taken as endogenous due to the fact that countries with lower per capita income are prioritized to receive official development assistance and aid ${ }^{62}$.

54 ICRG, 2011.

55 FRH, 2012.

56 FRH, 2012.

57 Acemoğlu et al., 2001.

58 WDI, 2017.

59 WDI, 2017.

60 WDI, 2017.

61 WDI, 2017.

62 Rajan, R. G. and Subramanian, A. (2008). Aid and Growth: What does the Cross-Country Evidence Really Show?, 


\section{The Governance in LDCs}

Figure 6.1 points out that LDCs can be characterized by a clear deficit in good governance institutions compared to high-income OECD countries supporting the argument of Acemoğlu et al. ${ }^{63}$ that economies that are different for a variety of reasons will differ both in their institutions and in their income per capita.

Since initial per capita incomes in the distant path were not very different across countries, the current dispersion in per capita incomes reflects differences across countries in growth in the very long run ${ }^{64}$. Hence, Figure 6.1 presents both the relationship between governance and income per capita in the short run and the relationship between governance and growth in the long run.

Figure 6.1 also demonstrates that rich countries have afforded better institutions ${ }^{65}$.

Gambia has the highest overall governance score compared to Yemen and Angola that have the highest income per capita among LDCs, while Congo has the lowest overall governance score together with lowest income per capita. Also the divergence is higher for LDCs than for highincome OECD countries.

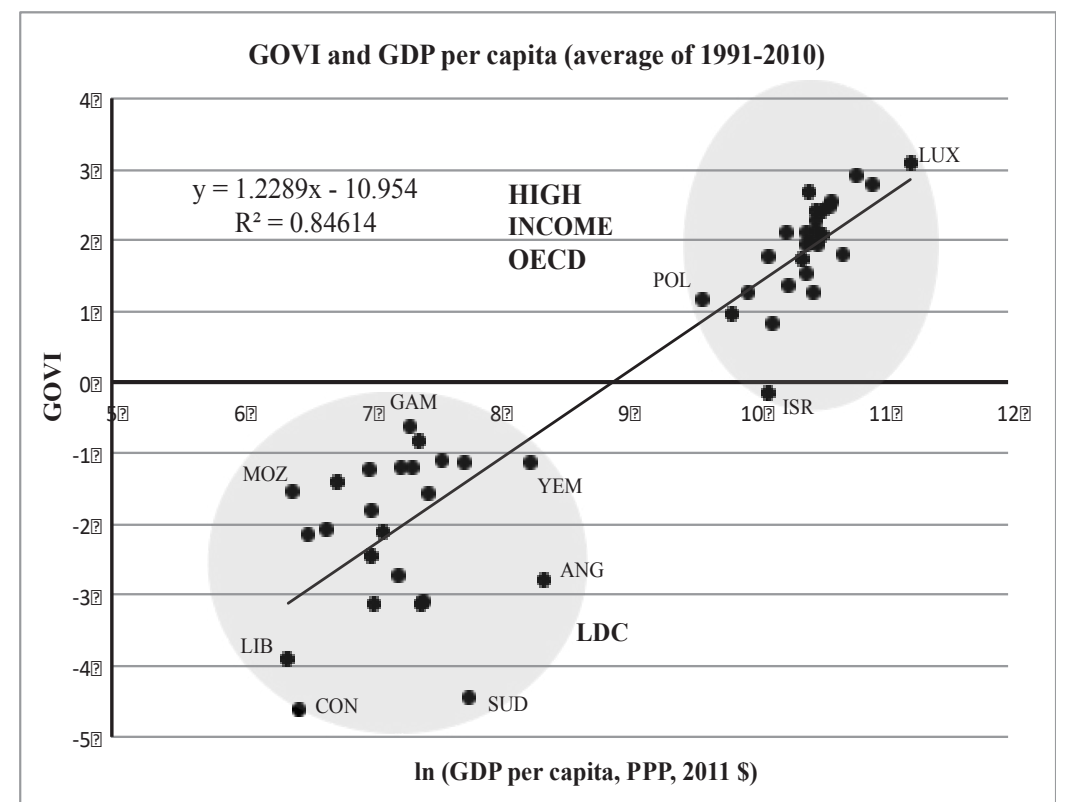

Figure 6.I: The Relationship between Overall Governance and Income per Capita

The Review of Economics and Statistics, 90(4): 643-665.

63 Acemoğlu et al., 2001.

64 Kaufmann, D., Kraay, A. (2002). Growth without Governance, The World Bank, Washington, D.C.

65 Acemoğlu et al., 2001. 


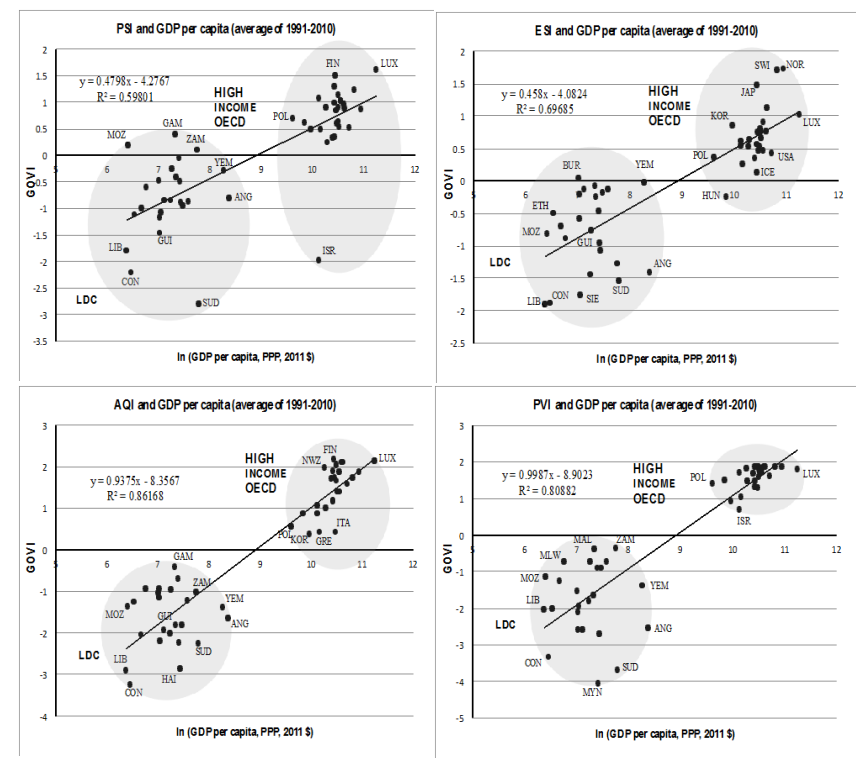

Figure 6.2: The Relationship between Governance Variables and Income per Capita

Figure 6.2 demonstrates the relationship between each governance index and income per capita. For the political stability index, all LDCs except Congo and Sudan have better performance than a high-income OECD country, Israel. Gambia has the highest political stability score among LDCs, while Sudan has the lowest political stability score for relatively higher income per capita. Burkina Faso and Yemen have the highest economic stability score among LDCs, even higher than a high-income OECD country, Hungary, while Congo and Liberia have the lowest score with lowest income per capita. Gambia has the highest administrative quality score, while Congo, Liberia and Haiti have the lowest score among LDCs. Mali and Zambia have the highest public voice score among LDCs, while Myanmar has the lowest score. Inspecting Figure 6.1 and Figure 6.2 , it seems that lowest income per capita always corresponds to worse governance quality, while highest income per capita does not correspond to better governance quality among LDCs.

(See Appendix 1 for the list of LDCs and high-income OECD countries)

\section{Empirical Analysis}

\section{I.Methodology}

The system GMM is designed for situations with small $\mathrm{T}$ and large $\mathrm{N}$ panels, with independent variables that are not strictly exogenous, meaning correlated with past and possibly current realizations of the error; with fixed effects; and with heteroskedasticity and autocorrelation 
within individuals ${ }^{66}$. Also, the system GMM method is employed to overcome reverse causality from dependent variable to independent variables.

Based on equation (3) in Section 2 with the modification of lag of income per capita as the initial value, $y_{0}$, the general model to be estimated with system GMM is as below;

$$
\begin{gathered}
(1.1) \mathrm{y}_{\mathrm{it}}=\propto \mathrm{y}_{\mathrm{i}, \mathrm{t}-1}+\mathrm{X}_{\mathrm{it}} \beta+\varepsilon_{\mathrm{it}} \\
(2.1)^{\varepsilon_{\mathrm{it}}}=\mu_{\mathrm{i}}+\mathrm{v}_{\mathrm{it}} \\
(3.1) \mathrm{E}\left(\mu_{\mathrm{i}}\right)=\mathrm{E}\left(\mathrm{v}_{\mathrm{it}}\right)=\mathrm{E}\left(\mu_{\mathrm{i}} \mathrm{v}_{\mathrm{it}}\right)=0
\end{gathered}
$$

The disturbance term $\mathrm{e}_{\mathrm{it}}$ has two orthogonal components as the fixed effects, $\mathrm{m}_{\mathrm{i}}$ and idiosyncratic shocks, $\mathrm{n}_{\mathrm{it}}$.

$$
\text { (4.1) } \Delta \mathrm{y}_{\text {it }}=(\alpha-1) \Delta \mathrm{y}_{\mathrm{i}, \mathrm{t}-1}+\Delta \mathrm{X}_{\mathrm{it}}^{\prime} \beta+\Delta \mathrm{v}_{\mathrm{it}}
$$

Assuming that changes in any instrumenting variable w are uncorrelated with the fixed effects.

(5.1) $\mathrm{E}\left(\Delta \mathrm{w}_{\mathrm{it}} \mu_{\mathrm{i}}\right)=0{ }^{67}$.

The system GMM estimator that is developed by Arellano and Bover ${ }^{68}$, Blundell and Bond ${ }^{69}$ augments the Difference GMM estimator that is developed by Arellano and Bond ${ }^{70}$ by making an additional assumption of the first differences of instrument variables are uncorrelated with the fixed effects (5.1), which allows the introduction of more instruments. Hence it can dramatically improve efficiency by building a system of two equations; one is the original equation (1.1), the other is the transformed one $(4.1)^{71}$. Hence, system GMM is preferred over difference GMM as the estimation technique.

Validity depends on the assumption that the $\mathrm{v}_{\text {it }}$ is not serially correlated. But if the vit is serially correlated of order 1 then, for instance, $\mathrm{y}_{\mathrm{i}, \mathrm{t}-2}$ is endogenous to the $\mathrm{v}_{\mathrm{i}, \mathrm{t}-1}$ in the error term in differences, $\Delta \varepsilon_{\text {it }}=\mathrm{v}_{\mathrm{it}}-\mathrm{v}_{\mathrm{i}, \mathrm{t}-\mathrm{1}}$, making it a potentially invalid instrument. The researcher would need to restrict the instrument set starting with third lag or longer. If the researcher finds second order correlation, he or she would need to start with even longer lags ${ }^{72}$.

66 Roodman, D. (2009). How to Do xtabond2: An Introduction to Difference and System GMM in Stata, Stata Journal, 9(1): 86-136.

67 Roodman, 2009.

68 Arellano, M., Bover, O. (1995). Another Look at the Instrumental Variable Estimation of Error-Components Models, Journal of Econometrics, 68(1): 29-51.

69 Blundell, R., Bond, S. (1998). Initial Conditions and Moment Restrictions in Dynamic Panel Data Models, Journal of Econometrics, 87(1): 115-143.

70 Arellano, M., Bond, S. (1991). Some Tests of Specification for Panel Data: Monte Carlo Evidence and an Application To Employment Equations, The Review of Economic Studies, 58(2): 277-297.

71 Roodman, 2009.

72 Roodman, 2009. 
Reduced From Equation;

$$
\begin{aligned}
& \text { (1.2) } y_{i t}=\propto y_{i, t-1}+\beta_{1} \text { gov }_{i t}+\beta_{2} \text { humcap }_{\text {it }}+\beta_{3} \text { gfcf }_{\text {it }}+\beta_{4} \operatorname{lntrop}_{\text {it }}+\beta_{5} \operatorname{lnaa}_{\text {it }}+\varepsilon_{i t} \\
& (2.2) \varepsilon_{\mathrm{it}}=\mu_{\mathrm{i}}+\mathrm{v}_{\mathrm{it}} \\
& \text { (3.2) } \mathrm{E}\left(\mu_{\mathrm{i}}\right)=\mathrm{E}\left(v_{\mathrm{it}}\right)=\mathrm{E}\left(\mu_{\mathrm{i}} v_{\mathrm{it}}\right)=0 \\
& \text { (4.2) } \Delta \mathrm{y}_{\mathrm{it}}=\delta \mathrm{y}_{\mathrm{i}, \mathrm{t}-1}+\phi \Delta \mathrm{gov}_{\mathrm{it}}+\lambda \Delta \text { humcap }_{\mathrm{it}}+\mu \Delta \mathrm{gfcf}_{\mathrm{it}}+\theta \Delta \operatorname{lntrop}_{\mathrm{it}}+\gamma \Delta \operatorname{lnaa_{\text {it}}}+\mathrm{v}_{\mathrm{it}} \\
& \text { (5.2) } E\left(\Delta w_{i t} \mu_{i}\right)=0
\end{aligned}
$$

$y_{i t}$ represents natural logarithm of GDP per capita for country i in year t. $y_{i, t-1}$ represents natural logarithm of GDP per capita for country i in year $\mathrm{t}-1$. gov $_{\text {it }}$ represents governance indicators, psi, esi, aqi, pvi and govi for country i in year t. humcap ${ }_{i t}$, gfcf $_{\text {it }}$ represent human capital and physical infrastructure, respectively for country i in year t. Introp represent natural logarithm of trade openness and $\operatorname{lnaa}_{\text {it }}$ represent net official development assistance and official aid received by country $i$ in year $t$.

\subsection{Estimation Results}

According to the estimation results in Table 7.1, improvement in any dimension of governance and the improvement in overall governance quality leads to increase in income per capita. Hence governance quality is a positive significant determinant of economic growth in LDCs. Political stability seems to be more significant than other dimensions of governance.

Improvement in political stability (psi) in the sense that more cohesive government, low ethnic and religious tensions together with diminishing internal and external conflicts decrease the occurrence of political violence leading to devotion of resources to favorable economic objectives resulting in growth by increasing total factor productivity.

Improvement in economic stability (esi) provides more adequate and consistent economic policies, which reduces cost of investments by removing risks and uncertainties in business environment leading to growth mainly through investment channel.

Improvement in administrative quality (aqi) in the sense of low level of corruption, better quality of bureaucracy, more sound and safer business environment lowering the risks for investors and better law and order leads to growth mainly through investment channel.

Improvement in public voice (pvi) leads to growth through both channel by providing checks and balances on elected officials, which in turn reduces arbitrary government intervention, lowers the risk of policy reversal and strengthens the private property protection and by enlarging the preference set of consumers. The results confirm the argument of compatibility school in the sense 
that democracy enhances economic growth, because the existence of fundamental civil liberties and political rights generates the social conditions, which are most conducive to economic growth ${ }^{73}$.

Lag of income per capita has positive significant coefficient less than unit in each regression, which suggests that income per capita in LDCs converges to its own steady-state level as in the case of income club-convergence (Tebaldi and Mohan, 2009).

Table 7.I: System GMM Estimation Results

\begin{tabular}{lccccc}
\hline Governance Variable & $p s i$ & esi & aqi & $p v i$ & govi \\
\hline \multirow{2}{*}{ Ingdppc } & $0.8842^{* * *}$ & $0.9076^{* * *}$ & $0.9002^{* * *}$ & $0.9236^{* * *}$ & $0.9241^{* * *}$ \\
& $(0.0622)$ & $(0.0609)$ & $(0.0520)$ & $(0.0553)$ & $(0.0675)$ \\
governance & $0.0349^{* * *}$ & $0.0177^{* *}$ & $0.0412^{*}$ & $0.0356^{* *}$ & $0.0247^{* * *}$ \\
& $(0.0093)$ & $(0.0075)$ & $(0.0207)$ & $(0.0135)$ & $(0.0057)$ \\
humcap & $0.0386^{* *}$ & $0.0208^{* *}$ & $0.0344^{* *}$ & $0.0345^{* *}$ & $0.0188^{* * *}$ \\
& $(0.0151)$ & $(0.0097)$ & $(0.0128)$ & $(0.0146)$ & $(0.0054)$ \\
gfcf & 0.0018 & 0.0002 & 0.0018 & 0.0008 & 0.0040 \\
& $(0.0036)$ & $(0.0018)$ & $(0.0020)$ & $(0.0023)$ & $(0.0028)$ \\
lntrop & -0.1217 & -0.0161 & -0.0119 & -0.0265 & -0.0890 \\
& $(0.0728)$ & $(0.0318)$ & $(0.0399)$ & $(0.0330)$ & $(0.0530)$ \\
lnaa & -0.0232 & -0.0065 & -0.0151 & -0.0204 & -0.0274 \\
& $(0.0154)$ & $(0.0208)$ & $(0.0146)$ & $(0.0207)$ & $(0.0163)$ \\
cons & $1.8034^{* *}$ & 0.8815 & $1.1154 *$ & $1.1291^{* *}$ & $1.4470^{* *}$ \\
AR(2) & $(0.7020)$ & $(0.5602)$ & $(0.6061)$ & $(0.5422)$ & $(0.6077)$ \\
Hansen & 0.891 & 0.722 & 0.973 & 0.944 & 0.501 \\
\# of Instruments & 0.624 & 0.383 & 0.314 & 0.291 & 0.242 \\
\# of Groups & 15 & 19 & 13 & 13 & 14 \\
\# of Obs. & 21 & 21 & 21 & 21 & 21 \\
\hline
\end{tabular}

Notes: The values in parenthesis are robust standard errors. ${ }^{* *},{ }^{* *}$ and ${ }^{*}$ denote significance levels at $\% 1, \% 5$ and $\% 10$ respectively. $\operatorname{AR}(2)$ is test for second-order serial correlation in the second - differenced residuals, under the null of no serial correlation. Hansen test of over-identification is under the null that all instruments are valid. Lagged dependent variable is taken as predetermined and all other independent variables are treated endogenously. Appropriate minimum of second to maximum of fourth lags of predetermined and endogenous variables were instrumented according to $\mathrm{AR}(2)$ test of serial correlation with lag collapse option.

Estimation results also suggest that human capital is another positive significant determinant of growth. It is robust in the sense that it has positive significant coefficient in each panel setting with different governance variable. The main rationale for positive significant effect of human

73 Feng, Y. (1997). Democracy, Political Stability and Economic Growth, British Journal of Political Science, 27(3): 391-418. 
capital on growth is that improvements in health conditions together with better educational attainment enhance labor productivity.

All other control variables seem robustly insignificant for growth in LDCs. The reason for the insignificant effect of official assistance and official aid (lnaa) may due their indirect effect on growth since improving governance, not boosting income per capita, above a certain level is a prerequisite for grant from UN and other donor countries. It supports the argument of Rajan and Subramanian ${ }^{74}$ that for aid to be effective in the future, the aid apparatus will have to be rethought. The insignificant coefficient found for trade openness (lntrop) supports the study of Raihan $^{75}$, which is done for specific LDC, Bangladesh.

\section{Conclusion}

According to the results of empirical analysis, improvement in governance institutions leads to increase in income per capita. Hence governance quality is a positive significant determinant of economic growth in LDCs.

Least developed countries are generally ex-colonies, did not find a chance to establish their own governance structures since they are ruled by the regimes of colonizers for many years. When they thought they won their independence, they were ruled by totalitarian regimes left behind and supported by advanced countries of today for sustaining political stability of the region or securing their economic interests. The colonial state and extractive institutions persisted even after independence.

Better governance leads to 'more adequate and consistent economic policies, which reduces cost of investments by removing risks and uncertainties in business environment', decreases 'the occurrence of political violence leading to devotion of resources to favorable economic objectives, provides more adequate and consistent economic policies, which reduces cost of investments by removing risks and uncertainties in business environment', increases 'the administrative efficiency by low level of corruption, better quality of bureaucracy, more sound and safer business environment lowering the risks for investors', reduces 'the arbitrary government intervention, lowers the risk of policy reversal and strengthens the private property protection and by enlarging the preference set of consumers. All of these facets of governance contribute to growth by improving politic, economic, administrative and democratic stand of state against internal and external events.

Although the adoption of first-best governance institutions of advanced countries to LDCs is not a panacea to sustain economic growth or development, improvement of first-best governance institutions significantly induce growth. The main rationale lies in the conclusion of Globerman

74 Rajan, R. G., Subramanian, A. (2008). Aid and Growth: What does the Cross-Country Evidence Really Show, The Review of Economics and Statistics, 90(4): 643-665.

75 Raihan, S. (2008). Trade liberalization and poverty in Bangladesh, Mpra Paper, No: 37905. 
and Shapiro (2002) that investments in governance infrastructure are subject to diminishing returns, so that the benefits are most pronounced for smaller and developing economies (including LDCs), even though they implied the benefits of foreign direct investment inflows.

Hence these low-income countries should allocate resources to improve their democracy, bureaucracy, politic and economic stability as aspects of governance and also to improve their human capital. Since governance and human capital are only positive significant determinants of income per capita growth.

\section{References}

ACEMOĞLU, D., JOHNSON, S., ROBINSON, J. A. (2001). The Colonial Origins of Comparative Development: An Empirical Investigation, American Economic Review, 91(5): 1369-1401.

ACEMOĞLU, D., JOHNSON, S., ROBINSON, J. A. (2005). Institutions as a Fundamental Cause of LongRun Growth, Handbook of Economic Growth, 1: 385-472.

AHRENS, J. (2002). Governance and Economic Development: A Comparative Institutional Approach, Edward Elgar Publishing.

AISEN, A., VEIGA, F. J. (2013). How does Political Instability Affect Economic Growth?, European Journal of Political Economy, 29: 151-167.

AlESINA, A., PEROTTI, R. (1994). The Political Economy of Growth: A Critical Survey of the Recent Literature, The World Bank Economic Review, 8(3): 351-371.

ANGELES, L. (2010). Institutions and Economic Development. New Tests and New Doubts, Sire, No: 201075.

ARELlanO, M., BOND, S. (1991). Some Tests of Specification for Panel Data: Monte Carlo Evidence and an Application to Employment Equations, The Review of Economic Studies, 58(2): 277-297.

ARELLANO, M., BOVER, O. (1995). Another Look at the Instrumental Variable Estimation of ErrorComponents Models, Journal of Econometrics, 68(1): 29-51.

ASIEDU, E., LIEN, D. (2011). Democracy, Foreign Direct Investment and Natural Resources, Journal of International Economics, 84(1): 99-111.

AYSAN, A. F., NABLI, M. K., VEGANZONES-VAROUDAKIS, M. A. (2007). Governance Institutions and Private Investment: An Application to the Middle East and North Africa, The Developing Economies, 45(3): 339-377.

BESLEY, T. (1995). Property rights and investment incentives: Theory and evidence from Ghana, Journal of Political Economy, 103(5): 903-937.

BLUNDELL, R., BOND, S. (1998). Initial Conditions and Moment Restrictions in Dynamic Panel Data Models, Journal of Econometrics, 87(1): 115-143.

CHONG, A., CALDERON, C. (2000). Causality and Feedback between Institutional Measures and Economic Growth, Economics \& Politics, 12(1): 69-81.

DAWSON, J. W. (1998). Institutions, Investment, and Growth: New Cross-country and Panel Data Evidence, Economic Inquiry, 36(4): 603-619.

DECKER, J. H., LIM, J. J. (2008). What Fundamentally Drives Growth? Revisiting the Institutions and Economic Performance Debate, Journal of International Development, 20(5): 698-725.

DELLEPIANE-AVELLANEDA, S. (2010). Good Governance, Institutions and Economic Development: Beyond the Conventional Wisdom, British Journal of Political Science, 40(1): 195-224. 
EASTERLY, W., LEVINE, R. (2003). Tropics, Germs, and Crops: How Endowments Influence Economic Development, Journal of Monetary Economics, 50(1): 3-39.

EFENDIC, A., PUGH, G., ADNETT, N. (2011). Institutions and Economic Performance: A Meta-Regression Analysis, European Journal of Political Economy, 27(3): 586-599.

ETZIONI, A. (2008). Security First: For a Muscular, Moral Foreign Policy, Yale University Press.

FENG, Y. (1997). Democracy, Political Stability and Economic Growth, British Journal of Political Science, 27(3): 391-418.

FEYRER, J., SACERDOTE, B. (2009). Colonialism and Modern Income: Islands as Natural Experiments, The Review of Economics and Statistics, 91(2): 245-262.

FRH (2012). Freedom in the World Database, Freedom House, New York.

GLOBERMAN, S., SHAPIRO, D. (2002). Global Foreign Direct Investment Flows: The Role of Governance Infrastructure, World Development, 30(11): 1899-1919.

HALL, S. G., AHMAD, M. (2014). Revisiting the Institutions-Growth Nexus in Developing Countries: The New Evidence, New Zealand Economic Papers, 48(3): 301-312.

HALL, R. E., JONES, C. I. (1999). Why do some Countries Produce so much more Output per Worker than others?, The Quarterly Journal of Economics, 114(1): 83-116.

ICRG (2011). International Country Risk Guide, PRS Group, New York.

KAUFMANN, D., KRAAY, A. (2002). Growth without Governance, The World Bank, Washington D.C.

KNACK, S., KEEFER, P. (1995). Institutions and Economic Performance: Cross-Country Tests Using Alternative Institutional Measures, Economics \& Politics, 7(3): 207-227.

MANKIW, N. G., ROMER, D., WEIL, D. N. (1992). A Contribution to the Empirics of Economic Growth, The Quarterly Journal of Economics, 107(2): 407-437.

NORTH, D. C. (1991). Institutions, The Journal of Economic Perspectives, 5(1): 97-112.

NORTH, D. C., THOMAS, R. P. (1973). The Rise of the Western World: A New Economic History, Cambridge University Press.

RAIHAN, S. (2008). Trade Liberalization and Poverty in Bangladesh, Mpra Paper, No: $37905 .$.

RAJAN, R. G., SUBRAMANIAN, A. (2008). Aid and Growth: What does the Cross-Country Evidence Really Show?, The Review of Economics and Statistics, 90(4): 643-665.

RODRIK, D. (2008). Second-Best Institutions, American Economic Review, 98(2): 100-104.

RODRIK, D., SUBRAMANIAN, A., TREBBI, F. (2004). Institutions Rule: The Primacy of Institutions over Geography and Integration in Economic Development, Journal of Economic Growth, 9: 131-165.

ROODMAN, D. (2009). How to Do xtabond2: An Introduction to Difference and System GMM in Stata, Stata Journal, 9(1): 86-136.

ST AUBYN, M. (2008). Modernising Public Administration and Economic Growth, Gpeari Working Paper, No: WP-001.

TEBALDI, E., MOHAN, R. (2009). Institutions-Augmented Solow Model and Income Clubs. A Economia em Revista-Aere, 17(2): 5-14.

WDI (2017). World Development Indicators, The World Bank, Washington D.C. 


\section{Appendix I: The List of LDCs and High Income OECD Countries}

List of LDCs Covered in the Study

\section{List of LDCs Covered in the Study}

\begin{tabular}{lll} 
& \multicolumn{2}{c}{ Africa (20 of 33) } \\
\cline { 2 - 3 } Angola & Liberia* & Sierra Leone \\
$\begin{array}{l}\text { Burkina Faso } \\
\text { Congo, Democratic Republic }\end{array}$ & Madagascar & Sudan \\
Ethiopia & Malawi & Togo \\
Gambia & Mali & Uganda \\
Guinea & Mozambique & Tanzania \\
Guinea-Bissau & Niger & Zambia* \\
& Senegal & \\
Bangladesh & Asia (3 of 14) & Yemen \\
Notes: * denotes LDCs that are not covered in Empirical Analysis. & \\
& Myanmar* & \\
Haiti & Latin America and the Caribbean (1 of 1) \\
\end{tabular}

List of High Income OECD Countries Covered in The Study

$\begin{array}{lll}\text { Australia } & \text { Hungary } & \text { New Zealand } \\ \text { Austria } & \text { Iceland } & \text { Norway } \\ \text { Belgium } & \text { Ireland } & \text { Poland } \\ \text { Canada } & \text { Israel } & \text { Portugal } \\ \text { Denmark } & \text { Italy } & \text { Spain } \\ \text { Finland } & \text { Japan } & \text { Sweden } \\ \text { France } & \text { Korea, South } & \text { Switzerland } \\ \text { Germany } & \text { Luxembourg } & \text { United Kingdom } \\ \text { Greece } & \text { Netherlands } & \text { United States }\end{array}$




\section{Appendix 2: Panel Unit Root Tests}

\begin{tabular}{|c|c|c|c|}
\hline Variable & Case & IPS & LLC \\
\hline \multirow{2}{*}{$\operatorname{lng} d p p c$} & Constant & 3.3291 & 2.6643 \\
\hline & Constant and Trade & $-2.6568^{*}$ & $-5.5799 *$ \\
\hline \multirow{2}{*}{ govi } & Constant & $-1.5584^{*}$ & $-5.1531^{*}$ \\
\hline & Constant and Trade & -0.5730 & $-3.9800^{*}$ \\
\hline \multirow{2}{*}{ psi } & Constant & $-3.7024^{*}$ & $-5.5181 *$ \\
\hline & Constant and Trade & -0.6698 & $-4.1176^{*}$ \\
\hline \multirow{2}{*}{ esi } & Constant & 1.4848 & $-2.8793^{*}$ \\
\hline & Constant and Trade & $-3.3765^{*}$ & $-5.7969^{*}$ \\
\hline \multirow{2}{*}{$a q i$} & Constant & $-6.2595 *$ & $-6.3697^{*}$ \\
\hline & Constant and Trade & $-4.1165^{*}$ & $-5.6233^{*}$ \\
\hline \multirow{2}{*}{$p v i$} & Constant & $-4.2805^{*}$ & $-6.5844^{*}$ \\
\hline & Constant and Trade & $-1.5880^{*}$ & $-5.2008^{*}$ \\
\hline \multirow{2}{*}{ humcap } & Constant & 9.7202 & 7.7703 \\
\hline & Constant and Trade & 1.2007 & $-2.9370^{*}$ \\
\hline \multirow{2}{*}{$g f c f$} & Constant & $-2.1160 *$ & $-2.9012 *$ \\
\hline & Constant and Trade & $-2.3090^{*}$ & $-3.6573^{*}$ \\
\hline \multirow{2}{*}{ lntrop } & Constant & $-2.8888^{*}$ & $-5.8719^{*}$ \\
\hline & Constant and Trade & $-4.2385^{*}$ & $-5.5177^{*}$ \\
\hline \multirow{2}{*}{$\ln a a$} & Constant & 1.7832 & 1.0038 \\
\hline & Constant and Trade & -0.1000 & $-3.8012^{*}$ \\
\hline
\end{tabular}

Notes: The null hypothesis for LLC and IPS are unit root. The numbers are corresponding test statistics. $\left(^{*}\right)$ denotes significance at $5 \%$ level, meaning the rejection of the null of unit root. 